\title{
Postponement of the next GTA conference to 2022
}

The $22^{\text {nd }}$ scientific workshop of the Society for Gestalt Theory and its applications were planned for June 2021 in Trieste (Italy).

However, it is still uncertain how the corona-related epidemiological situation will develop. This uncertainty will also have a massive impact on the organization of the conference in the next few months. It is also uncertain when and if travel and accommodation options and conference conditions will be available on site. There is a danger that organizational measures already initiated by the conference committee in Trieste will prove to be in vain due to new and further developments.

For these reasons and after intensive consideration, the GTA board, together with the organizers in Trieste, has decided to postpone the conference planned for next year to June 2022, also in Trieste.

We are confident that by 2022 conditions will have returned to normal enough that a large, ambitious conference can be planned and held again. We would be very happy to welcome you all to Trieste in 2022 and thank Prof. Agostini, Prof. Cattaruzza and Dr. Coppola for the further planning and preparations for the 22 nd scientific working conference.

\section{GTA Board}

Hellmuth Metz-Göckel, Marianne Soff, Silvia Bonacchi, Angelika Böhm, Thomas Fuchs 


\section{Verschiebung der nächsten GTA-Tagung auf das Jahr 2022}

Die 22. Wissenschaftliche Arbeitstagung der Gesellschaft für Gestalttheorie und ihre Anwendungen war für Juni 2021 in Triest (Italien) geplant.

Es ist derzeit aber noch unsicher, wie sich die Corona-bedingte epidemiologische Situation weiterentwickelt. Diese Unsicherheit wird auch in den nächsten Monaten die Organisation der Tagung massiv beeinträchtigen. Es ist ebenfalls unsicher, wann und ob Reise- und Unterkunftsmöglichkeiten und Tagungsbedingungen vor Ort zur Verfügung stehen werden. Es besteht so die Gefahr, dass sich bereits in die Wege geleitete Organisationsmaßnahmen durch das Tagungskomitee in Triest durch neue und weitere Entwicklungen als vergeblich erweisen.

Aus diesen Gründen und nach intensiven Überlegungen hat der GTA-Vorstand daher zusammen mit den Organisatoren in Triest beschlossen, die für das nächste Jahr geplante Tagung auf Juni 2022, ebenfalls in Triest, zu verschieben.

Wir sind zuversichtlich, dass sich im Jahre 2022 die Verhältnisse wieder soweit normalisiert haben, dass wieder eine große, anspruchsvolle Konferenz geplant und abgehalten werden kann. Wir würden uns sehr freuen, Sie alle 2022 in Triest begrüßen zu dürfen, und danken Prof. Agostini, Prof. Cattaruzza und Dr. Coppola für die weiteren Planungen und Vorbereitungen zur 22. Wissenschaftlichen Arbeitstagung.

\section{GTA-Vorstand}

Hellmuth Metz-Göckel, Marianne Soff, Silvia Bonacchi, Angelika Böhm, Thomas Fuchs 